\title{
The Qianlong-Era Yargiyan kooli ci tukiyeme tucibuhe fe manju gisun i bithe (Book of Old Manchu Expressions Extracted from the Veritable Records) and Qing Historians Today
}

\author{
CHIA NING \\ Central College
}

The 1766 Yargiyan kooli ci tukiyeme tucibuhe fe manju gisun i bithe is a historically significant collection of words, phrases, and sentences from the earliest Manchu-language Veritable Records (Shilu) and old archives intended as an aid to reading them. This research note outlines the history of the text and its compilation, as well as modern scholarly studies of it. It discusses the value of Yargiyan kooli ci tukiyeme tucibuhe fe manju gisun $i$ bithe to a Qing historian today and suggests it as a self-study guide to advance Manchu language skills for research. An appendix offers a number of examples with scholarly clarifications thereof in order to illustrate this usefulness.

\section{《論乾隆年間撰〈舊清語辭典〉對現今清史學 家之利用價值》}

\section{賈寧}

中部學院

摘要

《舊清語辭典》(又名《實錄內擇出舊清語》《《實錄內摘出舊清語》)撰於1766年, 收錄前三 朝《實錄》及重抄《無圈點檔》後成為《加圈點字檔》中的大量舊清語詞句, 並用新清語逐條 釋解, 以指導讀者領會原文。該《辭典》史學價值頗高, 清史學者應充分重視對它的使用。本 篇介紹《辭典》的歷史背景和編撰過程, 推萀趙志強先生的研究成果, 闡述《辭典》對當今清 史學家既提升滿語水平又學習原始資料的雙利價值, 並在附錄內提供實例與分析, 以饗讀 者。 
Introduction

In 1766, a history-focused dictionary written in Manchu came to its completion, and the Qianlong emperor (r. 1736-95) approved its title as Yargiyan kooli ci tukiyeme tucibuhe fe manju gisun $i$ bithe. The title means "Book of Old Manchu Expressions Extracted from the Veritable Records." A direct translation of this Manchu title into modern Chinese would yield cong shilu zhong zhaichu de lao Manwen ciyu de shu 從實錄中摘出的老 滿洲詞語的書. However, this work, which is written entirely in Manchu, has received three different Chinese titles since the Qing period.

Ihing 宜興 (1747-1809), a member of the Aisin Gioro Clan who compiled The Supplementary Dictionary of the Manchu Language (Ma. manju gisun be niyeceme isabuha bithe; Ch. Qingwen buhui 清文補彙) in 1786, first referred to this work as Shilu nei zechu jiuqingyu 實錄內擇出舊清語 (Old Manchu Expressions Excerpted from the Veritable Records). Two late-twentieth-century bibliographies, The Global Catalog of Manchu Texts (Shijie Manwen wenxian mulu 世界满文文献目录) and The National Union Catalog of Manchu Books and Materials (Quanguo Manwen tushu ziliao lianhe mulu 全国满文图书资料联 合目录) ${ }^{1}$ listed the work as Selected Old Manchu from the "Veritable Records" (Shilu nei zhaichu jiu Qingyu 实录內摘出旧清语). Xinjiang renmin chubanshe in Urumqi reprinted this work in 1987 and gave it the Chinese title Dictionary of the Old Manchu Language (Jiu Qingyu cidian 旧清语辞典). ${ }^{2}$ There is thus no consensus on how the book should be called in Chinese. This research note will use the 1987 edition to discuss this work and refer to it as The Dictionary below.

The Dictionary is the collection of Manchu words, phrases, and sentences taken from the early Veritable Records (shilu 實錄), the court chronicles compiled upon the death of a Qing ruler. It contains over eight hundred entries, ${ }^{3}$ and each entry is annotated with an explanation and description. A reader may find it problematic to label this work a cidian 辭典 "dictionary." Since the order of entries is chronological and follows the flow of the Shilu texts (in other words, the work does not use alphabetical or thematic arrangement), it is, in a sense, what in English-language scholarship is called a "glossary,"

1. Fu Li 富丽, Shijie manwen wenxian mulu 世界满文文献目录 [The Global Catalog of Manchu Texts] (Beijing: Zhongguo minzu guwenzi yanjiuhui, 1983), 161; Huang Runhua 黄润华 and Qu Liusheng 屈六生, Quanguo Manwen tushu ziliao lianhe mulu 全国满文图书资料联目录 [The National Union Catalog of Manchu Books and Materials] (Beijing: Shumu wenxian chubanshe, 1991), 114.

2. Jiu Qingyu cidian 旧清语辞典 (Wulumuqi: Xinjiang renmin chubanshe, 1987). Web image of Yargiyan kooli ci tukiyeme tucibuhe fe manju gisun $i$ bithe, see Manchu.work, http://www.manchu.work/books/18 (accessed February 23, 2021).

3. The Sibe postscript of The Dictionary (519) states that the book contains 800 entries (jakūn tanggū dulere meyen "eight hundred segments"). Zhao Zhiqiang, by contrast, says 807 entries: 648 from the first ten chapters, 52 from chapters 11-12, and 107 from chapters 13-14. (Zhao Zhiqiang 赵志强, “Jiuqingyu” yanjiu—Manzhou zaoqi de yuyan yu wenhua《 旧清语》研究——满洲早期的语言与文化 [Beijing: Yanshan chubanshe, 2003], preface, 4, 7, and 12.) Chunhua, finally, states 814 entries. (Chunhua 春花, Qingdai Man, Mengwen cidian yanjiu 清代满蒙文词典研究 [Shenyang: Liaoning renmin chubanshe, 2008], 442.) 
to wit, a wordlist arranged according to "the order of a source text from which all lemmata are culled, whether selectively or not." 4 In comparison to other Manchu language reference works from the Qing period that more easily fit the current term "dictionary," the work under study here stands out in that it does not, like most Manchu-language dictionaries, mainly serve linguistic needs. The Dictionary was intended as a companion to the early Manchu Shilu. (See the following section.) It is thus a historiographical reference work. Moreover, the book hardly fits the modern Chinese terms used to refer to dictionaries, zidian 字典 (a preliminary dictionary for checking pronunciation and correct writing with simple enunciation), cidian 詞典 (a dictionary that presents explanations of the word's reading and writing with examples of phrases and usage), and cidian 辭典 (a comprehensive dictionary with grammar guidance, knowledge content, and example sentences for a word). However, of these three, it is closest to the latter cidian, and one may thus arguably define The Dictionary as an encyclopedia of the early Shilu texts that presents two stages of the Manchu language, namely the stages before and after the Qianlong-era standardization of Manchu known in the literature as "imperially approved new Manchu" (qinding xin Qingyu 欽定新清語). The title Jiu Qingyu cidian, chosen as the Chinese title of the 1987 reprint of the reference work, can be understood in contrast to xin Qingyu in this sense. The title has become widely accepted by scholars in China. Chunhua, a specialist on Manchu and Mongolian language and dictionary studies, for example, listed this work as a Manchu dictionary of a particular kind. ${ }^{5}$ The reader should understand the specific purpose and style of The Dictionary before using it, as well as the reason why it is called a "dictionary" today. Chunhua's study provides the brief but noteworthy conclusion that The Dictionary created a wordlist in which the lemmata occur in the order of their appearance in the Veritable Records, a kind of dictionary that she calls a "dictionary in chronological order" shixu cidian 时序 词典. This kind of dictionary is very unique and was never widely adopted within Qing dictionary writing. ${ }^{6}$

Particular attention should be paid to what "new Manchu" and "old Manchu" refer to in the context of The Dictionary. In the English-language scholarly literature, "old Manchu" generally refers to Manchu as written before the orthographic reform of the 1630s, that is, the script without the diacritics known as the "dots and circles" (tongki fuka), or lao Manwen 老滿文 in Chinese. In this context, "new Manchu," or xin Manwen 新滿文 in Chinese is, then, the script with diacritics, meaning standard written Manchu as it was used from the 1630s onward. Crucially for the purposes of this paper, the shilu

4. Rolando Ferri, "The Greco-Roman World" in The Cambridge World History of Lexicography, ed. John Considine (New York: Cambridge University Press, 2019), 84.

5. Chunhua, Qingdai Man, Mengwen cidian yanjiu, 441.

6. Chunhua, Qingdai Man, Mengwen cidian yanjiu, 444. According to Zhao, there were exceptions in which the appearance order was not exactly followed. (Jiuqingyu cidian yanjiu, 2.) 
that form the source material for The Dictionary date from 1636 onward, and thus do not fall within the scope of "old Manchu" in the sense discussed above. As mentioned, the 1987 reprint titled the book as a dictionary of jiu Qingyu “old Qing language." Even though the two phrases jiu Qingyu and lao Manwen both translate into English as "old Manchu," they should be differentiated clearly. The postscript to The Dictionary, written in Sibe by the 1987 reprint team, pointed out that the Manchu language used before the Qianlong regulation and standardization is called "old Manchu" (Ma. fe manju gisun, Ch. jiu Qingyu), and after Qianlong's regulation and standardization, "new Manchu" (Ma. ice manju gisun, Ch. xin Qingyu):

In the middle of the Qianlong period, the Qianlong emperor gathered the most knowledgeable scholars in the Manchu language [and] standardized and regulated a huge list of the Manchu terms. . . . After this, [people] called the language before the standardization "old Manchu," [and] the language after the standardization "new Manchu."

abkai wehiyehe dulimbai forgonde, ciyanlung ejen manju šu de šumin hafu bithesisa be isabufi, manju gisun hergen be emu mudan amba durugani teksileme dasataha. . . . . . ere amala uthai teksilere onggoloi gisun be "fe manju gisun" sehe, teksilenhe amalai gisun be "ice manju gisun" sehebi. ${ }^{7}$

Thus, for the study of The Dictionary, "old Manchu" and "new Manchu" refer to two stages of the language. The "new Manchu" in the study of The Dictionary does not refer to the script with diacritics that was introduced in the early 1630s (i.e., what in Chinese would be called xin Manwen as opposed to xin Qingyu). In the other words, the English translation of "Old Manchu" and "New Manchu" must be understood in the background of the Manchu language reforms in different stages of Manchu and Qing history. Four different Chinese terms were associated with these two English translations.

\begin{tabular}{lll} 
English & Type of Manchu & Chinese \\
\hline Old Manchu & 1. Pre-1632 Manchu without dots and circles & 老滿文 lao Manwen \\
& 2. 1632-1740s Manchu with dots and circles & 舊清語 jiu Qingyu \\
New Manchu & 1. Manchu with dots and circles directly after & 新滿文xin Manwen \\
& 1632 & 新清語 xin Qingyu \\
& 2. Post-1740s Manchu, which replaced pre-1740s \\
& Manchu
\end{tabular}

With such an understanding, we read the entries and annotated comments in The Dictionary. See the following example. ${ }^{8}$

7. Sibe postscript to Yargiyan kooli ci tukiyeme tucibuhe fe manju gisun i bithe, 518.

8. Jiu Qingyu cidian, 190 and Zhao Zhiqiang, Jiu Quingyu yanjiu, 252. 
[Entry (old Manchu [jiu Qingyu], quotation from Shilu):] ere jihengge cohome suweni jalinde kai. uttu hendume ohode. tere gaiharilame donjirakū mujanggao (This coming person [or someone's coming this time is] especially for you [or for your sake]! Thus said, can it be true that he won't suddenly [come to] listen [or to follow my saying]?)

[Annotation (using new Manchu [xin Qingyu] to explain the entry's old Manchu)]: ere gaiharilame serengge. uthai gaitai ulhime safi sere gisun inu. tuttu fe gisun de, ere jihengge. cohome suweni jalinde kai. uttu hedume ohode. tere gaiharilame donjiraku mujanggao seme gisurembi. (This saying of gaiharilame or "suddenly" is just [equal to saying the phrase of] gaitai ulgime safi or "suddenly understand and know." So, in the old Manchu, it says that "This coming person [or someone's coming this time is] especially for you [or for your sake]! Thus said, can it be true that he won't suddenly [come to] listen [or to follow my saying]?")

[Note:] By this explanation, the old Manchu in the entry meant that "This person or the people who came did it especially for your sake! Thus said already, how come one won't immediately become understood [Ch. dunwu 頓悟] and [still] won't follow [Ch. shuncong 順從] [my words]?”

In sum, I will use "old Manchu" to refer to standard Manchu as used before the introduction of new words under Qianlong. More specifically, I will use this term in reference to the early Manchu Shilu, which were written using the script with the diacritic "dots and circles" but nevertheless contained numerous passages that were not easy to understand for Qianlong-era readers. I will in consequence reserve the term "new Manchu" to refer to the standardized Manchu of the eighteenth century and later.

The new words and phrases that separate "old" and "new" Manchu as discussed in this paper were essentially neologisms introduced to replace loanwords from Chinese or fill lacunae in the Manchu lexicon. ${ }^{9}$ As mentioned in the chart above, a number of Chinese publications have used the term qinding xin Qingyu 欽定新清語 to refer to the "new Manchu" established under the Qianlong emperor's supervision. Zhao Zhiqiang refers to the period initiated by Qianlong emperor's edict of 1747 regarding regulating and standardizing as "a period of transition from old Manchu to new Manchu" (xin-jiu Manyu de jiaoti shiqi 新旧满语的交替时期). He defines “new Manchu” as the Manchu language from Qianlong's standardization up until our present time. ${ }^{10}$ Chunhua defines "new Manchu" simply as the "Manchu established under the emperor's supervision"

9. This is what Mårten Söderblom Saarela's article "Public Inscriptions and Manchu Language Reform in the Early Qianlong Reign (1740s-1760s)," Saksaha 16 (2019-20): 31-53, refers to as an instance of "Manchu language reform."

10. Zhao Zhiqiang, Jiuqingyu yanjiu, preface, 3 and 16. 
(qinding Qingyu 欽定清語) and describes The Dictionary as using this new, Qianlong-era Manchu to explain the old Manchu of the early Shilu. ${ }^{11}$ Other Chinese-language publications discussed further below, edited by Tong Yonggong 佟永功, Guan Jialu 关嘉禄, Chuang Chi-fa 莊吉發, Zhang Hong 张虹 and Cheng Dakun 程大鲲, provide the readers with more studies for this round of old-to-new Manchu language transition.

A perusal of relevant bibliographical scholarship sheds some light on the publications through which Qianlong's "new Manchu” was promulgated, yet the limited work that has been done regarding these sources suggests that we cannot at present conclude with confidence how Qianlong's language reform was conceptualized and discussed at the time it was carried out. For instance, Huang Runhua and Qu Liusheng's union catalog lists a two-volume manuscript work with the Manchu title hesei toktobuha manju gisun and the Chinese title Imperially Established New Manchu Language [or Phrases] (Qinding xin Qingyu 欽定新清語). ${ }^{12}$ The Manchu title given here does not include ice “new," which, however, is present in the Chinese title. Two other items listed on the same page describe an eight-chapter book with the same Manchu title (hesei toktobuha manju gisun), but here its Chinese title is written as Imperially Established New Language [or Phrases] (Qinding xinyu 欽定新語). ${ }^{13}$ Chunhua's study of Manchu and Mongolian dictionaries introduces four editions of a book titled Imperially Established Manchu Language [or Phrases] (Qinding Qingyu 欽定清語) with the Manchu title han i toktobuha manju gisun. These four works are described as collections of new Manchu words and phrases introduced under Qianlong. ${ }^{14}$ The number of volumes comprising these works suggests that they are distinct from each other. None of them, furthermore, matches the twovolume Imperially Established New Manchu Language listed in Huang's and Qu's union catalog. Chunhua, however, points out that Imperially Established New Language might refer to the same work as the one referred to as Imperially Established Manchu Language in two other entries of Huang's and Qu's bibliography.

While the available bibliographies do not allow us to make any conclusions regarding how the language reform was understood and discussed by Qianlong's court scholars, the available descriptions show that Manchu-Chinese bilingual dictionaries containing the imperially approved words were written in order to codify the language reform. A systematic examination of these dictionaries promises to enrich our understanding of the historical context in which The Dictionary was compiled and the nature of the difficulties that a reader accustomed to "new Manchu" (in the sense of xin Qingyu) might have had with the old Manchu Shilu.

11. Chunhua, Qingdai Man, Mengwen cidian yanjiu, 442.

12. Huang and Qu, Quanguo Manwen tushu ziliao lianhe mulu, 118, item \#0470.

13. Items \#0470 and \#0471. Fu Li, Shijie Manwen wenxian mulu, 72, similarly lists these two works one after another but does not give the Manchu title.

14. Chunhua, Qingdai Man, Mengwen cidian yanjiu, 152-58. 
From Completion to Reprint

With no clear information on its beginnings, present-day scholars have posited the compilation of The Dictionary as the outcome of the Qianlong emperor's mandated annotation of two kinds of early Manchu court chronicles. The three early Manchu Veritable Records, commonly called "Veritable Records" of the First Three Reigns (Ch. Qian sanchao shilu 前三朝《實錄》), represent the first kind. The “Three Reigns" referred to were those of Nurhaci (r. 1616-26), Hong Taiji (r. 1626-36 [Tiancong] and 1636-43 [Chongde]), and the Shunzhi Emperor (r. 1643-61). I will continue to refer to them as the Shilu below. The early Manchu archives without diacritics represent the second kind, which Qing-period scholars referred to as The Archives Without Dots and Circles (Ma. Tongki fuka akū hergen -idangse; Ch. Wu quandian dang 無圈點檔). ${ }^{15}$ This archive became known to the scholarly world only belatedly. The Japanese scholar Naitō Torajirō 内藤虎次郎 (1866-1934), commonly known as Naitō Konan 湖南, in Mukden in 1905 discovered an edition of this old Manchu archive, in which the text had been edited and rewritten in the reformed script with diacritics. This revised edition of the original archive became known as "the old Manchu archive" (Ja. Manbun rōtō 滿文老 檔, Ch. Manwen laodang). A Beijing edition of Manwen laodang came to light in 1931. In the same year, parts of the original archive itself were discovered in the Palace Museum in Beijing, while another three volumes were found in 1935. This collection has become known as the "Old Manchu archive" (Ch. Jiu Manzhou dang 舊滿洲檔; Ma. Fe Manju dangse). This collection has been stored in the National Palace Museum in Taiwan since 1949. In 1963, Guanglu and Li Xuezhi, two scholars in Taiwan, named this collection Lao Manwen yuandang 老滿文原檔, literally The Original Old Manchu Archives, which they titled in English The Archives Without Dots and Circles. In the debate over this title, scholar in Taiwan, Ch'en Chieh-hsien, suggested using Jiu Manzhou dang 舊滿洲檔 instead of Lao Manwen yuandang. The archive was reprinted using this title in 1969. In 2005, a second reprint by the Taiwan National Palace Museum titled the collection The Original Manchu Archive (Manwen yuandang 滿文原檔). ${ }^{16}$ The complicated history of this archive, including the titles given it during the twentieth century, should be kept in mind when reading the last two chapters of The Dictionary.

Twelve of the fourteen chapters, or debtelin (Ch. juan 卷), of The Dictionary carry entries selected from the three early Shilu. The first of these works is The Veritable Records

15. Zhao Zhiqiang, Jiu Qingyu yanjiu, preface, 8.

16. Nobuo Kanda 神田信夫, “Cong Manwen laodang dao Manzhou jiudang” 从《满文老档》到《旧满洲挡》 [From the Old Manchu Archives to Fe Manju dangse], in Yan Chongnian 阎崇年, ed., Manxue yanjiu 满学研究 [Manchu Studies] (Beijing: Renmin chubanshe, 1996), vol. 3, 256-78; Wu Yuanfeng 吳元丰, “Manwen laodang chuyi” 满文老档刍议 [A Preliminary Discussion of the Old Manchu Archives], Qingshi yanjiu 1, no. 1 (February 2011): 138-45, 138; Yan Chongnian 阎崇年, “Wuquandian laodang ji Qianlong chaoben mingcheng quanshi”《无圈点老档》及乾隆抄本名称诠释, Lishi yanjiu 3 (1998): 49-64. 
of Taizu, Emperor Gao of the Great Qing (Ma. Daicing gurun i taizu horonggo enduringge hūwangdi yargiyan kooli; Ch. Daqing taizu gaohuangdi shilu 大清太祖高皇帝實錄). The first edition of this work dates from 1636, the second from 1655, and the third from 1686. The second work is The Veritable Records of Taizong, Emperor Wen of the Great Qing (Ma. Daicing gurun i taizung genggiyen šu hūwangdi i yargiyan kooli; Ch. Daqing taizong wenhuandi shilu 大清太宗文皇帝實錄). This work was first ordered during the Dorgon regency shortly after the conquest of Beijing. The Shunzhi emperor himself ordered the second compilation. The final compilation came in 1673. The third work covered in these chapters is The Veritable Records of Shengzu, Emperor Zhang of the Great Qing (Ma. Daicing gurun $i$ šizu eldembuhe hūwangdi i yargiyan kooli; Ch. Daqing shizu zhanghuangdi shilu 大清世祖章皇帝實錄). This text exists in an edition of $1672 .{ }^{17}$ In 1727 , the Yongzheng emperor (r. 1723-35) issued the order to annotate these three Shilu in the three languages of Manchu, Mongolian, and Chinese. The process produced a "finalized version" (dingben 定本) of the early Shilu in 1740 (Qianlong 5). Since the Yongzheng emperor did not ever order that they be updated to incorporate the changes that the Manchu language had undergone since the time these Shilu were written down, ${ }^{18}$ the Manchu readers of the early Qianlong reign could hardly follow the early oral sayings and expressions recorded in them. According to the Sibe postscript to The Dictionary, by the early Qianlong period, Manchu use and proficiency were faltering, and some expressions fell into complete disuse (. . . fe manju gisun be baitalarangge ulhiyen i gari oho, ememu be fuhali waliyafi baitalarkū ofi . . .). ${ }^{19}$

Unlike his father, the Qianlong emperor paid great attention to the changes of the Manchu language and launched a large-scale language regulation. With the Qianlong emperor's approval, The Dictionary project proceeded to guide readers of the early historical sources so the Manchu past would not be forgotten. According to the postscript to the reprinted The Dictionary, "in this book, there are eight hundred segments of old Manchu expressions which were selected from the Shilu. Inside it [the book], the idioms, slang sayings, and ritual terms which were popularly used during the earliest Manchu period were enumerated close together" (ere bithe de "cing guruni yargiyan kooli" ci konjome[?] tucibuhe fe manju gisun jakūn tanggū dulere meyen bi. tere dolo manju uksurai tuktan forgonde baitalame yabuha toktoho gisun, dekdeni gisun, koolingga gisun labdu kam-

17. For the Manchu titles of these three Shilu and their editions, see Huang Runhua and Qu Liusheng, Quanguo Manwen tushu ziliao lianhe mulu, 165-66. There are three ways to transliterate the three emperors' temple names. (1) Huang Runhua and Qu Liusheng, Quanguo Manwen tushu ziliao lianhe mulu, 165-66, uses "taizu," "taizung," and "xizu." Since their catalog gave the source titles in Manchu, I have followed their spelling, but changed their "x" into "š." (2) An Shuangcheng 安双成, Man-Han dacidian 滿漢大辭典 [Manchu-Chinese Dictionary], revised edition (Shenyang: Liaoning renmin chubanshe, 2018), which uses "taidzu," "taidzung" (596), and "šidzu” (576). Liliya M. Gorelova's Manchu Grammar concurs with An Shuangcheng (Leiden: Brill, 2002, 71-2). (3) Jerry Norman's A Comprehensive ManchuEnglish Dictionary (Cambridge, Mass.: Harvard University Asia Center, 2013), xxii, has "taicu," "taicung," and "šicu." 18. Chunhua, Qingdai Man, Mengwen cidian yanjiu, 255.

19. The Sibe postscript to Yargiyan kooli ci tukiyeme tucibuhe fe manju gisun $i$ bithe, 517. 
cibuhabi). ${ }^{20}$ Thus, The Dictionary served as an aid to the reading of the early historical records in Manchu.

As mentioned, the conception of The Dictionary in 1766 was an outcome of Qianlong's regulation of the Manchu language. Even though 1760 has been treated as the the dividing timeline between "old Manchu" and "new Manchu,"21 the effort at reforming the Manchu lexicon started already in the 1740s. Through the introduction of a great number of neologisms, the Qianlong court standardized many Manchu words and phrases covering social, cultural, political, and economic aspects of Qing life. In the early Qing period, when Manchus adopted Chinese words, they phonetically transliterated the Chinese terms into Manchu. The Qianlong emperor opposed this practice and replaced the already transliterated terms with Manchu neologisms formed on the basis of Manchu morphology. For example, in 1747 the emperor replaced giyapu ("genealogy" < Ch. jiapu 家譜) with sirara hafan i sekiyen, ciyanzi ("label” < Ch. qianzi 簽字) with afahari, and hsing gung ("temporary imperial residence" < Ch. xinggong 行宮) with tatara gung. The Dictionary reflects this change, as the example from chapter 8 below shows, and educated Manchu readers to understand old Manchu and to learn new Manchu. ${ }^{22}$ In the process of creating these Manchu neologisms, the Qianlong court looked at each central or local governing institution, 260 in total, and checked whether its name fit the New Manchu criteria, then decided to approve it as it was or change it. It also re-named all of the noble ranks and official titles in Manchu. Vocabulary revision and creation affected the words in religious and ceremonial rituals, from Chinese philosophical and classical traditions, to items in the Manchu palace services, to various goods in people's daily life, and to plants and animals in the natural world. A study of the Imperial Household Department Archives (Shengjing Neiwufu dang 盛京內務府檔), for instance, has indicated 1,700 new Manchu phrases. Many aspects of pronunciation and grammar accompanied these changes. ${ }^{23}$ The distinguishing feature of The Dictionary is its role of bridging the old Manchu and new Manchu by employing the latter to explain the former.

20. The Sibe Postscript to Yargiyan kooli ci tukiyeme tucibuhe fe manju gisun i bithe, 519.

21. Zhao, Jiu Qingyu yanjiu, preface, 3.

22. Tong Yonggong 佟永功 and Guan Jialu 关嘉禄, “Qianlongchao 'Qinding xinqingyu' tanxi” 乾隆朝“钦定新清语”探析, Manzu yanjiu 2 (1995): 66-70, 66-67. For the examples, see Zhang Hong 张虹 and Cheng Dakun 程大鲲, trans., and Tong Yonggong 佟永功, proofread, “Qianlongchao “Qinding xin Qingyu (1)” 乾隆朝 “钦定新清语”(一) [“Imperially Approved New Manchu” of the Qianlong Reign (1)], Manyu yanjiu 2 (1993): 79-84 and 55, 81.

23. Chuang Chi-fa 莊吉發, “Tulichen Yiyu lu Manwenben yu Hanwenben de bijiao” 圖理琛「異域錄」滿文本與漢文本的比 較, http://manchusky.blog.sohu.com/37987646.html; Chunhua, Qingdai Man, Mengwen cidian yanjiu, 152-53; Tong Yonggong 佟永功, Manyuwen yu Manwen dang'an yanjiu 满语文与满文档案研究 (Shenyang: Liaoning renmin chubanshe, 2009), 33 and 40-57; Zhang and Cheng, trans., "Qianlongchao 'Qinding xin Qingyu' (1)”; "Qianlongchao 'Qinding “Qianlongchao 'Qinding xin Qingyu' (2)” 乾隆朝“钦定新清语 (二)” [Imperially Approved New Manchu of the Qianlong reign (2)], Manyu yanjiu, 2 (1994): 68-77 and 50; “Qianlongchao 'Qinding xin Qingyu' (3)” 乾隆朝“欽定新清語”(三) [Imperially Approved New Manchu of the Qianlong reign (3)], Manyu yanjiu, 2 (1995): 51-58; "Qianlongchao 'Qinding xin Qingyu' (4)” 乾隆朝 “欽定新清語”(四)” [Imperially Approved New Manchu of the Qianlong reign (4)], Manyu yanjiu 2 (1996): 31-38; “Qianlongchao ‘Qinding xin Qingyu’ (5)” 乾隆朝“钦定新清语”(五) [Imperially Approved New Manchu of the Qianlong reign (5)], Manyu yanjiu 2 (1997): 37-44. 
Completion of the first ten chapters of The Dictionary came in early 1766, followed soon by another two chapters, which added entries not in the original plan. The twelve chapters contained 700 old Manchu entries with annotations in new Manchu to explain each of them. In 1768, the court distributed 80 printed copies of these twelve chapters to the Manchu high-ranking nobles and officials for them to study and continue the Manchu heritage. ${ }^{24}$

The last two chapters of The Dictionary collected 107 entries from the 37 volumes of the old Manchu archive without dots and circles. Of these earliest Manchu archives, already in disorder and serious damage in Qianlong's time, the emperor ordered re-copying with the addition of diacritics, thus producing The Archives with Dots and Circles (Ma. tongki fuka sindaha hergen i dangse; Ch. Jia quandian zi dang 加圈點字檔), a copy of which Naitō Konan found in Mukden in 1905 (as discussed above), in the seventh month of 1776 . Compilation of the two chapters of The Dictionary on this archival project came in the tenth month of that year, and their printed volumes became available in 1778, thus making The Dictionary a total of fourteen chapters. ${ }^{25}$

The Dictionary contained no prefatory material. It began with chapter one and ended at chapter fourteen, providing no information of author and publication year. Each of the fourteen chapters was thread-bound into an individual volume, and fourteen volumes were placed into a book box. ${ }^{26}$ Three eminent Qing officials, Fuheng (1720-70), Šuhede (1710-77), and Agūi (1717-97), succeeded as the heads of The Dictionary project, demonstrating how important the project was. ${ }^{27}$ Today a palace edition (dianban 殿 版 or dianben 殿本) copy—the highest quality of book printing at Wuyingdian 武英殿 inside the Forbidden City — of The Dictionary is a valuable holding of the Palace Museum in Beijing. ${ }^{28}$ Another five palace edition copies can be found at The National Library of China, Inner Mongolia Library, Qiqihar City Library, Liaoning Provincial Library, and Nanjing Library. ${ }^{29}$ Of the eighty copies distributed in 1768 (comprising the twelve chapters) and 1778 (for the last two chapters), the Shengjing (Mukden) military governor, Heilongjiang military governor, and Jilin military governor each had a copy in his office. After the Qianlong emperor granted the other seventy-seven copies to Manchu nobles and officials, some additional locally reproduced copies became an educational

24. Zhao, Jiu Qingyu yanjiu, Preface, 3 and 5-7.

25. Zhao, Jiu Qingyu yanjiu, Preface, 7-12. Huang Runhua and Qiu Liusheng, Quanguo Manwen tushu ziliao lianhe mulu, 164, lists the edition of tongki fuka sindaha hergen $i$ dangse as dating from 1775, one year earlier than Zhao's date. For the re-copying process, see Wu Yuanfeng, "Manwen laodang chuyi," 139-41.

26. Sibe postscript to Yargiyan kooli ci tukiyeme tucibuhe fe manju gisun i bithe, 516.

27. Zhao, Jiu Qingyu yanjiu, preface, 1-19, 16.

28. Web image of the dianben 殿本 of Yargiyan kooli ci tukiyeme tucibuhe fe manju gisun i bithe: The Palace Museum, "Shilu nei zhaichu jiu Qingyu," online at https://www.dpm.org.cn/ancient/nation/159730.html (accessed February 23, 2021).

29. Chunhua, Qingdai Man, Mengwen cidian yanjiu, 441. 
resource for lower-level officials and bannermen to carry on the old Manchu language and cultural traditions. ${ }^{30}$

Currently, the following libraries around the world hold Xinjiang renmin chubanshe's 1987 reprint copy of The Dictionary: Institute for Advanced Study Library, Stanford University Library, Waseda University Library, National Taiwan University Library, and The University of Melbourne Library. The Dictionary was the first of seven Xin-jiang renmin chubanshe's Manchu language reprints produced during 1987-2006. ${ }^{31}$ The publisher released five hundred copies of The Dictionary reprints to the book market in 1987, which significantly opened this research resource to scholarly use beyond the museum display and a few library copies, all with restricted availability.

The reprint edition joined the previously separate fourteen chapters into one volume and kept The Dictionary entirely Manchu as it originally was. It adds an entry index of 91 pages before chapter one to assist readers' entry search in the fourteen chapters comprising 515 pages. Chunhua mentioned a "General Outline" (zonggang 總綱) which was discovered as an attachment only to the Qiqihar Library copy. Chunhua did not have a chance to review this general outline, ${ }^{32}$ and it awaits scholarly examination. The reprint entry index is arranged in the order of the Manchu alphabet, ${ }^{33}$ with exceptions here and there. Its order is in the same structure as but constitutes a shortened form of the $a$ uju (the first section of the syllabary) of juwan juwe uju (the "twelve syllabic headings," Ch. shi'er zitou 十二字頭). It runs from "a" only through "w." The length of the chapters of The Dictionary varied sharply, such as 101 entries and 42 pages of the first chapter and 21 entries and 13.5 pages for the twelfth chapter. ${ }^{34}$ The Chinese title appears only once among the bibliographical information on the very last page. The reprint working team developed a Yarusun or Introduction (Ch. daoyan 導言) of thirteen pages and Amalai ejebun or Postscript (Ch. houji 後記) of seven pages, both written in Sibe. Yarusun provides the background of Xinjiang renmin chubanshe's deligent efforts

30. Zhao, Jiu Qingyu yanjiu, preface, 12-5.

31. The six others were Man-Han hebi liubu chengyu 满汉合璧六部成语 [Manchu and Chinese combined dictionary for idioms of the Six Boards] (1990), Man-Han hebi liubu chengyu Man-Han hebi xixiangji (Sibe language) 滿漢合璧西廂 記 [Manchu and Chinese combined Romance of the Western Chamber] (1991), Yuzhi fanyi shijing 御製翻譯詩經 [The emperor-edited translation of Classic of Poetry] (1992), Man-Han hebi guwen 滿漢合璧古文 [Manchu and Chinese combined Ancient Writing] (1993), Man-Han hebi Liaozhai zhiyi xuanyi 滿漢合璧聊齋誌異選譯 [Manchu and Chinese combined Strange Tales from the Chatting Studio, Selected Translantion] (1994), and Liubu chengyu 六部成語 [Idioms of the Six Boards] (2006). https://book.douban.com/series/3700. Accessed on February 22, 2021.

32. Chunhua, Qingdai Man, Mengwen cidian yanjiu, 444.

33. This research note does not involve the debate between the syllabic theory and alphabetical one of the Manchu script but follows Gertraude Roth Li's "Manchu alphabet." For the debate, see Gertraude Roth Li, Manchu: A Textbook for Reading Documents (Honolulu, Hawaii: University of Hawai'i Press, 2000), 16, and for "Sequence of the Manchu alphabet," see 375.

34. The Dictionary, 1-42, 428-441; Zhao, Jiu Qingyu yanjiu, preface, 2 and 7. 
to publish minority nationalities' historical books. The Amalai ejebun gives a review of the background, compilation, Qing publication, and 1987 reprint of The Dictionary.

The Scholarly Value

The Dictionary is a Manchu language textbook, a quotation collection of the three early Shilu, and a history reading guide. The primary purpose of using it is not for learning or checking a word. It is for learning the Manchu language by reading Qing history or learning Qing history by reading the Manchu language text. The classification of The Dictionary in Manchu bibliography has reflected such a combined nature between a dictionary and a historical work. The World Manchu Bibliographical Catalog lists it under “History" (lishi 历史), and the National Union Catalog of Manchu Books and Materials, in the section of “Dictionary and Wordlist Books" (Ch. cidian, cihuiji 辞典、词汇集). ${ }^{35}$ As a self-learning resource for advanced Manchu, one reads The Dictionary, or a part of it, to achieve fruitful outcomes in language learning and historical research. As a resource to guide a researcher in working on the early Shilu, The Dictionary may help a historian establish all-rounded Manchu language skills more effectively than using many other dictionaries or reference resources. ${ }^{36}$

Entries from the early Shilu cover a broad range of content while providing varied vocabulary, phrases, and sample sentences to illustrate early Manchu. The annotation comments employ common synonyms from the Qianlong period to describe lost items from old Manchu. In addition, not all of the selected entries were out of date but still in use, as Zhao Zhiqiang has pointed out (see Sample Entries below). A reader can effectively build vocabulary by reading The Dictionary and acquiring new words and their synonyms. Reading The Dictionary, furthermore, engages the reader in grammar review and advancement since the entries and their annotations embody most, if not all, of the Manchu grammar phenomena and show how grammar rules were applied in historical writings. As vocabulary and grammar acquisition further increase one's reading comprehension, the interlocution of the old and new Manchu benefits one in both early and later Qing history reading. Vocabulary growth, grammar advancement, and reading proficiency simultaneously promote one's translation skills, which are decisive to a research project.

Many present-day Manchu readers and learners are likely more familiar, if not

35. Fu Li, Shijie Manwen wenxian mulu, 161; Huang and Qu, Quanguo Manwen tushu ziliao lianhe mulu, 114.

36. For a brief list of Manchu or multilingual dictionaries or guidebooks, see He Ling 贺灵, “Qingdai Manwen wenxian gailun” 清代满文文献概论 [A General Introduction to the Manchu literature of the Qing Dynasty] in Xibo wenhua 38, online at http://www.iqh.net.cn/info.asp?column_id = 8388, accessed October 23, 2020. For a more complete list, see Huang Runhua and Qu Liusheng, Quanguo Manwen tushu ziliao lianhe mulu, Section Six, Languages, 76-129. 
solely familiar, with new Manchu, since language education has leaned towards the resources in new Manchu. According to Japanese scholar Imanishi Shunjū 今西春秋 (1907-79), old Manchu, or "ancient Manchu" in his words, was not within the scope of original Qing dictionaries and language books such as The Manchu Language Dictionary (Ma. Manju gisun i buleku bithe; Ch. Qingwenjian 清文鑑) and Collection of Manchu Writing (Ma. Manju isabuha bithe; Ch. Qingwen huishu 清文彙書). ${ }^{37}$ The most important Manchu reference dictionary in the twentieth century, Haneda Toru's 羽田亨 (18821955) Manju ži-ben Gisun Kamcibuha Bithe or Man-Wa jiten 滿和辭典 (Manchu-Japanese Dictionary), did not include the words of the pre-conquest period either. ${ }^{38}$ With the overwhelming number of the Qing reference works being on the side of new Manchu, The Dictionary's reference value in listing old and new Manchu side-by-side should receive significant attention. Reading through The Dictionary, one can easily find that, without the annotated explanations written in the new Manchu, the entries in old Manchu expressions could be misread or confused in many cases. Because The Dictionary integrates new Manchu to such a high degree, while The Dictionary can support a historian entering into the specialty of early Manchu archives, it also helps those working with records written in new Manchu.

Beyond its significance as a language guide, the entries and annotations of The Dictionary deliver encyclopedic knowledge about Manchu culture, history, folklore, and ethnography, which every researcher in the Qing and Manchu studies would need as a foundation. According to Zhao Zhiqiang, The Dictionary was in heavy use during the Qing dynasty for history writing, archival sorting, and fact-checking. Today, if Manchu archival specialists try to solve difficulties in reading and translation, The Dictionary can be expected to bring clarification and resolution. ${ }^{39}$

Establishing a clear contrast and comparison between the early Manchu language with strong oral influence and the eighteenth-century Manchu language under the Qianlong regulation, The Dictionary brings the history gain along with the language enrichment to a degree hard for other Manchu reference works to match. A Qing historian should study The Dictionary regardless of the research period and for both the language and knowledge.

Thus, a Qing historian using Manchu as research language will find The Dictionary an essential resource to help advance grammar knowledge, understand the differences between old and new Manchu as used in Qing historical sources, improve reading comprehension, and aid in the research of the most challenging historical records for the

37. Zhao, Jiu Qingyu yanjiu, preface, 2.

38. Haneda Toru 羽田亨, Manju Ži-ben gisun kamcibuha bithe = Man-Wa jiten 滿和辭典 [Manchu-Japanese Dictionary], (Kyoto, [1937] 1972), cited in Yan Chongnian 阎崇年, Ershi shiji shijie manxue zhuzuo tiyao 20世纪世界满学著作提要 (Beijing: Minzu chubanshe, 2003), 288.

39. Zhao, Jiu Qingyu yanjiu, preface, 17-18. 
early history of Manchu state-building, that is, the time of Nurhaci, Hong Taiji, and the Shunzhi emperor.

\section{Scholarly Studies of The Dictionary}

Imanishi Shunjū devoted himself to the study of The Dictionary and published "ChiuCh'ing-Yü Translated and Explained” (Ja. Kyū Shingo yakkai 旧清語訳解). ${ }^{40}$ While this work is significant as the first systematic study of The Dictionary, the unavailability of the Manchu edition of the Shilu during his research time limited his success because part of his examination of The Dictionary could only rely on the Chinese edition. He thus stated that his work only reduced the level of the reading difficulty but did not reach the level of research. ${ }^{41}$

The Study of the "Old Manchu Language"-Language and Culture of the Early Manchu (“Jiu Qingyu” yanjiu—Manzhou zaoqi de yuyan yu wenhua《旧清语》研究——满洲早期 的语言与文化), written by the Sibe scholar Zhao Zhiqiang in Beijing and published by Yanshan chubanshe in 2003, represents the highest achievement in the present study of The Dictionary. ${ }^{42}$ It is a current reference book to assist the study of the historical reference book The Dictionary. Not only was Zhao able to examine the Manchu editions of the Shilu to comment on each entry of The Dictionary, Zhao also consulted many other Manchu references, both Qing and post-Qing, when examining each entry and its annotation. His discussion of The Dictionary brought both Manchu language development and historical knowledge about Shilu studies into the twenty-first century. As he confirms the high value of The Dictionary as an "irreplaceable" work for Qing scholars, Zhao also points out three problems from the compiling process of The Dictionary to direct researchers away from confusion. The first problem is that some entries do not keep the original Shilu text but have been shortened or revised by the compiler. Secondly, some Manchu words remained alive during Qianlong's time, so they did not belong to "old Manchu" at that time or even now. Finally, certain annotations display some degree of imprecision. ${ }^{43}$

In his well-structured, 513-page guide, Zhao places each entry and its annotation back into the text of the Shilu original to check its accuracy, freeing a reader from possible confusion that may arise when only reading isolated quotations. He then devel-

40. Imanishi Shunjū 今西 春秋, Kyū Shingo yakkai 旧清語訳解 [Chiu Ch’ing-Yü Translated and Explained], Monumenta Orientalia 3 (1969), 1-287.

41. See Zhao's summary of Imanishi Shunjū's work, Jiu Qingyu yanjiu, preface, 15-16.

42. Web image of Zhao Zhiqiang趙志強, Jiuqingyu yanjiu—Manzhou zaoqi de yuyan yu wenhua 舊清語研究——满洲早期的 语言与文化, Douban, online at https://book.douban.com/subject/2121699/, (accessed February 23, 2021).

43. Zhao, Jiu Qingyu yanjiu, 14, 18. 
ops a comprehensive examination of grammar by connecting each entry with known Qing Manchu reference works such as the Imperially Commissioned Pentaglot Dictionary (Han i araha sunja hacin i hergen kamciha manju gisun i buleku bithe | Yuzhi wuti Qingwen jian 御制五體清文鑒, 1957 reprint), ${ }^{44}$ the Imperially Commissioned Expanded Mirror for Studying Qing Writing (Han i araha nonggime toktobuha manju gisun i buleku bithe |Yuzhi zengding qingwenjian 御制增定清文鑒, 1771), Supplementary Dictionary of the Qing Language (Manju gisun be niyeceme isabuha bithe | Qingwen buhui 清文補彙, 1786), A Comprehensive Collection of the Manchu Language (Manju gisun i uheri isabuha bithe | Qingwen zonghui 清文總彙, 1897), Idioms for Memorial-Writing (or Phrasebook for Memorial Writing, Wesimbure bukdari i toktoho gisun | Zouzhe chengyu 奏摺成語, 1889), Phrasebook of Official Documents (Manju gisun i sonjofi sarkiyaha bithe | Gongwen chengyu 公文成 語, 1889), ${ }^{45}$ Reprinted Guide of Particles in the Qing [Manchu] Language (Dasame foloho manju gisun $i$ untuhun hergen i temgetu jorin bithe | Chongke qingwen xuzi zhinan 重刻清 文虛字指南, 1894), and so on. His grammatical discussion also takes reference from Manchu literary translations such as Romance of the Three Kingdoms (Ilan gurun $i$ bithe | San guo yan yi 三國演義, 1650), Romance of the Western Chamber in Manchu and Chinese (Manju nikan si siyang gi bithe | Man-Han hebi xixiangji 滿漢合璧西廂記, 1991 reprint), and Manchu and Chinese combined Strange Tales from the Chatting Studio, Selected Translation (Manju nikan liyoo jai jy i sonjoho bithe | Man-Han hebi liaozhai zhiyi xuanyi 满汉 合璧聊齋誌異選譯, 1992 reprint). He further verifies his grammatical analysis with the most important contemporary Manchu dictionaries such as Man-Han dacidian 满汉大辞 典 (1993), a dictionary which is particularly helpful to archival studies with ManchuChinese two-way translation; Xin Man-Han dacidian 新满汉大辞典 (1994)—another successful comprehensive Manchu dictionary; as well as textbooks such as Manyu yufa 满 语语法 (Manchu Grammar) and Manyu yanjiu tonglun 满语研究通论 (General Theory of Manchu Language Studies). ${ }^{46}$ Twenty-six Qing or post-Qing Manchu works ${ }^{47}$ assisted his textual investigation, rectification of mistakes, grammatical analysis, and clarification of annotations. Forty-seven grammar points ${ }^{48}$ in the context of Shilu writing through his book offers a reader the most complete introduction of the Manchu grammar studies of the recent PRC scholars.

Since the entries and annotations of The Dictionary are translated into Qing-era clas-

44. Note another recent edition: Oliver Corff et al., eds., Auf kaiserlichen Befehl erstelltes Wörterbuch des Manjurischen in fünf Sprachen „Fünfsprachenspiegel“ (Wiesbaden: Harrassowitz Verlag, 2013).

45. This work has another title as Qingyu zhaichao 清語摘抄. See Zhao, Jiu Qingyu yanjiu, 93, 111-12.

46. Ji Yonghai, Liu Jingxian, and Qu Liusheng, Manyu yufa (Beijing: Minzu chubanshe, 1986); Liu Jingxian, Zhao A'ping, and Zhao Jinchun, Manyu yanjiu tonglun (Harbin: Heilongjiang chaoxian minzu chubanshe, 1997).

47. Zhao, “Fulu 1 Benshu zhuyao yinyong shumu ji biaozhu fangshi” 附录1 本书主要引用书目及标注方式 [Appendix 1: The major books cited in this work and the annotation method], in Jiu Qingyu yanjiu, 483-84.

48. Zhao, “Fulu 2 Benshu sheji de zhuyao yuyan xianxiang” 附录2本书涉及的主要语言现象 [Appendix 2: The major language phenomena touched upon in this book], in Jiu Qingyu yanjiu, 485-86. 
sical Chinese, and Zhao's examination and discussion of them are written in modern Chinese, a learner can improve Manchu together with two forms of Chinese language simultaneously. Zhao's thoroughgoing work on the history side also reinforces The Dictionary's coverage of early Manchu social, cultural, economic, political, and folk life. A challenging but helpful reference, Zhao's work, again, can assist a scholar in achieving an advanced level of language and history studies.

Zhao's book focuses entirely on the first twelve chapters, that is, the chapters covering the early Shilu, since the early Manchu archives covered in the last two chapters have already received sufficient attention from scholars in Japan, Taiwan, and Mainland China. ${ }^{49}$ For example, the noted scholar Chuang Chi-fa's 莊吉發 publication of selected annotated portions of the old Manchu archives has propelled research on early archives to stronger ground. ${ }^{50}$

\section{Conclusion}

The reprint of Yargiyan kooli ci tukiyeme tucibuhe fe manju gisun $i$ bithe and the publication of Zhao Zhiqiang's The Study of the "Old Manchu Language" mark two milestones in Manchu language and Qing history studies. Because of them, old Manchu is no longer as absent in Manchu reference works. Connecting and comparing old Manchu and new Manchu becomes achievable through a self-guided learning process. In current language education in North America, self-learning is a key to raising a historian's Manchu skill levels, either through self-study without taking classes or searching for self-improvement after receiving the basic (or above the basic) Manchu language training. Following David Porter's online Self-Study Resources and the available Manchu textbooks and dictionaries, ${ }^{51}$ The Dictionary and Zhao's 2003 work significantly grant Manchu-learners higherlevel self-study resources to improve Manchu language skills. The effective use of these two references will promote the development of Qing history scholarship.

49. Zhao Zhiqiang, Jiu Qingyu yanjiu, Preface, 19. Also see Yan Chongnian, Wuquandian laodang ji Qianlong chaoben mingcheng quanshi and Ershi shiji shijie manxue zhuzuo tiyao, 336, 338, 341, 346, 350, 355, 357, 359, 370, 372, and 389.

50. Chuang Chi-fa 莊吉發, Manwen yuandang “Manwen yuandang” xuandu yizhu: Taizuchao (Yi) 滿文原檔《滿文原檔》選讀譯 註:太祖朝 (一) [The Original Manchu Archives, Selected and Annotated Original Manchu Archives: Taizu Reign, Part 1] (Taipei: Wenshizhe, 2020).

51. David Porter, "Self-study resources," Manchu Studies Group, online at https://www.manchustudiesgroup.org/selfstudy-resources/. For major recent textbooks and dictionaries in the PRC up to 2003, check Yan Chongnian, Ershi shiji shijie manxue zhuzuo tiyao, section 4 "Language," 288-335. For major resources since 2003, see Chia Ning, "The Manchu Language Resources in the People's Republic of China: A Comprehensive Review of Sixteen Manchu Textbooks," China Review International 16, no. 3 (2010): 308-22, Ji Yonghai 季永海, Manyu yufa 满语语法 [Manchu grammar], revised edition (Beijing: Zhongyang minzu daxue chubanshe, 2011), and Liu Housheng 刘厚生, Manyu jiaocheng 满 语文教程 [Course materials for Manchu language teaching] (Changchun: Jilin wenshi chubanshe, 1992). For major publications outside China, see Liliya M. Gorelova, Manchu Grammar: Handbook of Oriental Studies; Gertraude Roth Li, Manchu: A Textbook for Reading documents; Jerry Norman, A Comprehensive Manchu-English Dictionary; and Paul Georg von Möllendorff, A Manchu Grammar, With Analysed Texts: 1848-1901 (n.p.: HardPress Publishing, 2013). 
Figure 1: Sample page of The Dictionary's Gisun baicara yarusun (lit. "Introduction of checking words," lexical translation $<$ Ch. tiaomu chaxun suoyin 条目查詢索引), The Dictionary, 1. Illustration by the author, with the help of David Porter.

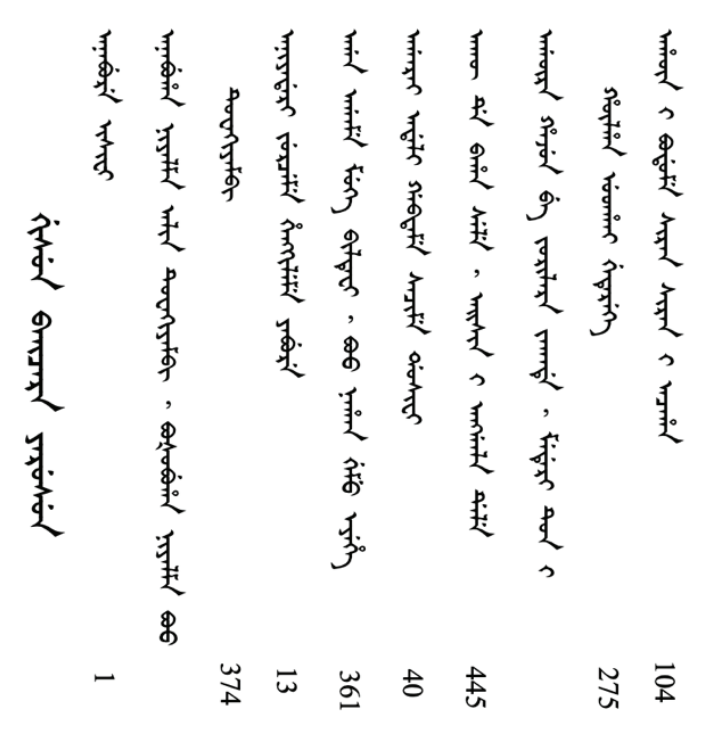

Sample Entries from The Dictionary and Zhao Zhiqiang, The Study of the "Old Manchu Language"

Neither The Dictionary nor Zhao's work are available in many U.S. libraries. Nor will purchasing them be easy either inside or outside of China nowadays. The sample entries below, one from each of the twelve chapters, are aimed at demonstrating the details of the two works, from The Dictionary entries and the annotations to them, to Zhao's quotations of the Shilu originals with the entries in them, and in both Manchu and Chinese languages (unless Zhao omitted them). The conclusions of Zhao's examination and his grammar guidance are summarized with highlights. The entry words/phrases/ sentences are marked bold in the Shilu quotations and English translation. The English translation of the Shilu quotation is placed in brackets [].

Ujui debtelin [The first chapter] entry 2, The Dictionary, 1, and Zhao, 21-22:

Entry: anabure isifi

Annotation: uthai anabure hamika sere gisun. fe gisun de. anabure isifi cooha baiha seme holbofi gisurembi

Zhao's Taizu Shilu quotation: ningguta i beise anabure isifi, hebdeme muse emu mafa de fuseke beise, juwan juwe gašan de teci facuhūn, ishunde dame aisilara de mangga, emu gašan de acafi teki seme gisureme wajiha hebe be, ineku soocangga i jui utai efuleme hendume, emu gašan de acafi adarame tembi, ulha ujirakū banjimbio, emu gašan de acafi tere be nakafi, mini amha hada i wan han de cooha baiki seme hendufi, cooha baifi, donggo i aiman be juwe jergi sucufi, ududu gašan be gaiha. 宁古 
塔贝勒几不能支, 相与谋日: “我等皆一祖所生, 分居十二处, 势涣散, 难相声援, 当聚族而 居。”即定议, 索长阿子吴泰又败其议, 日: “一处何可居乎? 将不为杽息畜产地呼?今不必聚 居, 借兵哈达万汗便。” 哈达万汗, 吴泰妇翁也。于是借兵, 攻董鄂部二次, 获其数寨。 [The Beile (plural) of Ningguta were almost defeated, [they thus] conspired together and said: "We all were born by one ancestor, [but now] live separately in twelve places. (Our) strength (has been) weakened, (one can) hardly support the other, (and we) should reside by gathering together." Right after the decision was made, Soocangga's son Utai turned against it and said: "How can we live (together) in one place? Won't the pastureland become impossible for raising (all of our) livestock? Today we don't have to reside together, (but can) borrow fighters from the Hada chief Wan (if we are in battle)." Hada chief Wan (is) Utai's father-in-law. Thus (the Beile of Ningguta) asked for military support (from chief Wan), attacked the Donggo (tribe) twice, and seized several of (Donggo's) villages.]

Zhao's analysis: anabure isifi is the oral expression of anabure de isifi which means, in direct translation, “very close to being defeated" (jiangji zhanbai 将及[战]败) and, in this Shilu context, "almost cannot hold oneself [from being defeated]" (ji bu neng zhi 几 不能支). Pre-1644 Manchu oral expressions often omitted part of a sentence, and de in this case is an example. This phenomenon, however, also existed in Manchu writings in later years of the Qing dynasty.

Zhao's grammar guidance: isifi, from the verb isimbi, must have de to connect to its object in formal writing. In this Shilu record, isifi does not function as an adverb, as it could in another context, but as a verb with equal standing to the other verbs in the complete sentence.

Jai debtelin [The second chapter], entry 43, The Dictionary, 67, and Zhao, 127-28.

Entry: baitangga weile

Annotation: ere bitangga weile sere gisun. uthai jingkini baita sere gisun. fe gisun de. jingkini baita be baitangga weile seme inu gisurembi:

Zhao's Taizu Shilu quotation: mentuhun i canggi acaha manggi, ceni dolo urgunjeme eficere, omire jetere bade ohode, beyebe efisi injesi arafi bisire, mergesei juleri ohode bulcara jailara, baitangga weile de takūraci siltara anatara oci, inu niyalmai duwali waka kai. 愚者群聚, 纵为嬉游, 耽于宴饮, 习于谑浪。至贤者当前, 则引故而却避 之。若委以正务, 则诿谢而不任焉。此亦非人类也。 [The fools bond in crowd gathering, wander around for unrestricted fun, overindulge in banquet and drinking, (and) accustom to unrestrained ridicule. Once a wise man stands in front (of them), (they) create a reason to run away. If given a decent task, (they) make an excuse and avoid taking it. These are not the appropriate people.]

Zhao's analysis: The direct translation of baitangga weile is "the matter which is 
useful” (youyong de shiqing 有用的事情) or “the matter which is necessary" (biyao de shiqing 必要的事情). In the Shilu context, it means undertaking “the right profession" (zhengwu 正務) rather than only enjoying life by partying and drinking.

Zhao's grammar guidance: baitangga becomes an adjective from the noun baita. Among the two meanings of weile, "crime" and "matter," the latter is taken in this case. $^{52}$

Ilaci debtelin [The third chapter], entry 14, The Dictionary, 94-95, and Zhao, 159-62.

Entry: te suwe beyebe arame kemuni dain i biki sembio

Annotation: ere dain i biki sembio sere gisun. uthai dain oki sere gūnin. fonjire arbun. tuttu fe gisun de. dain oki sere gisun be. dain i biki seme inu gisurembi:

Zhao's Taizu Shilu quotation: te suwe beyebe uru arame, kemuni dain i biki sembio? (今)尔尚自以为是, 与我为敌耶? [(Today) are you opinionated and view me as an enemy?]

Zhao's analysis: The entry left uru off from beyebe uru arambi, which means "opinionated," Chinese ziyiweishi 自以為是.

Zhao's grammar guidance: biki sembi is one of the optative verb forms (qingyuanshi 请愿式).

List of the six Manchu optative forms:

-rao, reo, roo for expression of a strong wish

-cina for a gentle suggestion

-ki for (1) wish the other to do something and (2) ask/or request the other to do

something

-kini for one's wish or hope

-ki sembi for one's want or desire with the following variations:

1. - ki seci for a conditional wish (ruoxiang 若想)

2. -ki sembime for the expression of even though thinking ... but ... (suixiang 虽想)

3. -ki sembihe for the tone of past wish (cengxiang 曾想)

4. - ki sehei for a continuous desire (yizhixiang一 直想)

5. -ki sehe for the state of already wanted (yixiang 已想)

52. This discussion of "weile" is a good reminder to The Dictionary readers that some modern dictionaries of Manchu particularly identify the ancient terms. For example, under the entry weile in Jerry Norman's A Comprehensive Manchu-English Dictionary, one can find "matter, affair, work, deed (especially in early texts)" (404a). In the best archive-oriented ManHan dacidian 滿漢大辭典 (Manchu-Chinese Dictionary), there are many such cases with the note "from old Manchu" (xi jiu Qingyu 系旧清语). 
6. -ki sehengge for what has been thought (suoxiang 所想)

7. -ki seme or -ki sere for thinking of or wishing of (xiangde 想的, xiangyao 想要)

8. -kini sembi for one's wish or hope

Duici debtelin [The fourth chapter], entry 52, The Dictionary, 162-63, Zhao, 226.

Entry: ududu aniya tuleri yabume booi duka be duleci dosikakū

Annotation: ere tuleri yabume sere gisun. uthai tule bigarame yabume sere gisun inu. fe gisun de. tule bigarame yabure be. tuleri yabume seme inu gisurembi:

Zhao's Taizong Shilu quotation: jakūn aniya tuleri yabume, ini booi duka be ilanggeri duleci dosikakūbi: 八年于外, 三过其门而不入. [Away from home for eight years, passed by home three times (but) did not enter.]

Zhao's analysis: tuleri here is used as an adverb to describe yabume (-mbi). tuleri yabume is not included in Qingwen buhui because it is not old Manchu and can be found in later Manchu writings.

Zhao's grammar guidance: The Manchu words for "outer" include tuleri, tule, and tulergi. Tule is the locative word, and the combination of tule and ergi ("side" or "direction") makes tulergi. Tuleri is a shortened form of tulergi. Accordingly, the words for "inner" include dolo, dorgi, and dolori. Dolo is the locative word, and dorgi and dolori both are the combinations of dolo and ergi. ${ }^{53}$

Sunjaci debtelin [The fifth chapter], entry 33, The Dictionary, 192, and Zhao, 253-54.

Entry: mini jihe songko be gene. acaha manggi. nikan i ergi be adame jio

Annotation: ere jihe songko be gene sere gisun. uthai jihe songko deri gene sere gisun de adali. ergi be adame jio serengge. uthai tubade isinaha manggi gaifi jio sere gisun inu. tuttu fe gisun de. mini jihe songko be gene. acaha manggi. nikan i ergi be adame jio seme gisurembi:

Zhao's Taizu Shilu quotation:《实录》原文, 满文与《旧语》同, 汉文为: 当从朕旋师旧 路而往, 会后, 可沿明边界护之而来。 [(In) the Shilu original, the Manchu matches The Dictionary entry. Its Chinese is: (You) should follow me (the emperor) and revolve (your) troop to reach (there) along the previous route. After meeting (with someone/some people), (you) can escort (him/them) to come back along the Ming border.]

Zhao's analysis: The entry matches the Shilu record exactly. Nikan here means "the

53. For the reader with interested in the grammar of this discussion, please see the comprehensive explanation in connection to tulergi in "Manchu and Mongolian Spatials" in José Andrés Alonso de la Fuente, "On the Role of Grammaticalization (Recategorization) in the Origin of Manchu Motion Verbs," Cahiers de Linguistique Asie Orientale 45, no. 2 (2016): 113-26, 115-20. 
Ming dynasty" in the Shilu context, and adame here functions as an adverb. Jio is the imperative form of jimbi. So, the correct translation of nikan i ergi be adame jio should be "come back by bringing the Ming side [of people] along" (xietong mingchao yifang qianlai 携同明朝一方前来). It corrects The Dictionary's annotation to the entry, which is tubade isinaha manggi gaifi jio which is "(after [you] have arrived there, [then] bring [someone/something] over [here])" (dao nali yihou dailai 到那里以后带来).

Zhao's grammar guidance: $B e$ has two functions. The first is to serve as the accusative case suffix to indicate the object of an action or behavior. In Chinese, it is $b a$ 把 or jiang 将. The second is to serve as a preposition to denote where the action or behavior takes place. In Chinese, it is $z i$ 自 or cong 从 which fits jihe songko be gene. Zhao thus agrees with the annotation of The Dictionary that mini jihe songko be gene means jihe songko deri gene, "go over [there] along [the track/road that] I came from" (congwo suolai zhi ji [lu] qianwang 从我所来之迹(路)前往).

Ningguci debtelin [The sixth chapter], entry 19, The Dictionary, 223-24, and Zhao, 282.

Entry: ice aniya juwe ilan inenggi onggolo. ihan tantara inenggi sarin dagilaha

Annotation: ere ihan tantara inenggi serengge. uthai niyengniyeri dosire inenggi inu. fe gisun de. niyengniyeri dosire inenggi be. ihan tantara inenggi seme gisurembi:

Zhao's Taizu Shilu quotation: ice aniyai juwe ilan inenggi onggolo ihan tantara inenggi sarin dagilafi, hacin hacin i buya efin be efibume, gosime sarilara gūnin be tucibuci acambi. 何不于岁前二三日设宴迎春, 而佐以各项杂剧, 以示宴享慈惠之意? [Why not set up the banquet to welcome spring two or three days before the New Year Day, and assist [the celebration] with various kinds of theater to evidence [your] benevolent and benefit-giving intention by (such) an enjoyable banquet?]

Zhao's analysis: The Dictionary correctly annotated that ihan tantara inenggi, directly translated as "the day of beating a cow," actually means niyengniyeri dosimbi which came sometime later for "the first day of spring" (lichun 立春). Whether the ihan tantara inenggi was the early concept of the Jurchen or early Manchu, or it was an accidental expression of that time, has remained a question. The clue is that folk customs in the land of ancient China included a popular celebration ritual for the spring day, and this celebration centered on the cow. According to that custom, people glued paper into a colorful cow on the Spring Day Eve and took the cow out to the public crowd at the first moment of the Spring Day. With the music band playing, everyone in the crowd used a silk whipper to flog the cow until the five kinds of food crops fell on the ground out of the broken paper cow. At this moment, people cheered loudly with their wish for a harvest year. This ritual celebration was called "beating the spring" (Ch. dachun 打春). The early Manchu saying "beating the cow" is likely the reflection of such a vivid scene of spring celebration. 
Nadaci debtelin [The seventh chapter], entry 39, The Dictionary, 278-79, and Zhao, 326-30.

Entry: weingge ohode amba weile arambi. weingge ohode ajige weile arambi

Annotation: ere neigen teksin akū be jorime gisurehengge. korsoro gūnin. weingge sere gisun. uthai we ningge sere gisun inu. tuttu fe gisun de. weingge ohode amba weile arambi. weingge ohode ajige weile arambi seme korsome gisurembi:

Zhao's Taizu Shilu quotation: 《实录》原文, 满文與《旧语》同, 汉文為: 何彼罪偏重, 此罪偏輕? [(In) the Shilu original, the Manchu matches The Dictionary entry. Its Chinese is: Why was that crime (convicted) weightily and this crime, minorly?].

Zhao's analysis: The Mirror for Manchu Language《清文鉴》, Collection of Manchu Writing 《清文汇书》, and Manchu-Chinese Dictionary 《滿漢大辭典》 have all included weingge, so this term is not old Manchu. The combination of we (who) and the suffix ningge, weingge means "whose" and was used often in the later Manchu writing.

Zhao's grammar guidance: The suffix ningge can appear at the end of a word, a phrase, and a sentence. When connecting to the verb before it, ningge is shortened as ngge, which has the following cases. ${ }^{54}$

1. ngge with perfective verb: -kangge, -kengge, -kongge, -hangge, -hengge, -hongge and negation: -hakūngge, -hekūngge

2. ngge with imperfective verb: -rangge, -rengge, -rongge and negation: rakūngge

3. ngge with verb akūmbi: akūngge

4. ngge with an adjective, such as olhocukangge, and ingge with an adjective, such as icengge

5. ngge with a noun, such as jibcangge, and ingge with a noun, such as enduringge

6. ningge with personal pronoun, such as bi becomes miningge, and ingge with beye becomes beyeingge

7. ngge with number, such as ujungge, ilacingge, and uducingge

8. ngge with locative word, such as wargingge and amargingge

9. ngge with a preposition, such as barungge

54. Grammatical explanations and analyses of ningge and ngge in different references will benefit a Manchu language learner to understand this important lexical phenomenon. Grammar books written by PRC scholars have supported Zhao's explanation about ningge and ngge. See Ji Yonghai 季永海, Manyu yufa, 140-41 and Liu Jingxian, Zhao Aping, and Zhao Jinchun, Manyu yanjiu tonglun《满语研究通论》[General Theory of Manchu Language Studies]. Harbin: Heilongjiang chaoxian minzu chubanshe, 1997, 185. Liliya M. Gorelova's Manchu Grammar discussed ngge as "the substantive-possessive suffix" and the case of adding it "to nouns in the attributive function." In this case, "the suffix -ngge is preceded by the marker of the genitive $i / n i$ and changes into the formant ningge which is mostly written separately from the noun. . . . some of them exhibited a tendency to shift from nouns to adjectives," and "a noun quality with the formant ningge - denotes a certain object..." See Lilya M. Gorelova, Manchu Grammar, 153-54. As Gorelova's discussion on ningge and ngge focused on nouns, Zhao's discussion here covers them with verb, adjective, noun, pronoun, number, locative word, and proposition. 
Jakūci debtelin [The eighth chapter], entry 22, The Dictionary, 307-9, and Zhao, 355-56.

Entry: dulimbai gurun be necihiyeme toktobuhangge. facaha sirge be dasara adali. da dube be baha de. ududu tumen juda bicibe. gulhun hergitu banjinambi. da dube be ufaraci. udu jušuru urhun i facaha sirge seme dasara de mangga ombi.

Annotation: ere duibulere gisun. facaha sirge serengge. uthai son son i fakcaha sirge inu. hūniha facuhūraha sere gūnin. hergitu serengge. gulhun jilkin be jorime gisurehengge. uthai hešen sere gūnin inu. facaha sirge i da be bahaci. teni hergime dasaci ombi sere gūnin. tuttu fe gisun de. da dube be baha de. ududu tumen juda bicibe. gulhun hergitu banjinambi. da dube be ufaraci. udu jušuru urhun i facaha sirge seme dasara de mangga ombi seme gisurembi:

Zhao's Taizu Shilu quotation: The entry quotation matches the Shilu record, except that toktobuhangge in The Dictionary entry was toktoburengge in Shilu, juda was jang, and jušuru was c'y. 《实录》原文汉文为: 㦲定中原, 如理乱丝。得其头绪, 即亿丈之条 缕可寻; 失其头绪, 即尺寸之乱丝难理。 [The Chinese in the Shilu text is: Pacifying the Central Plain (China proper) is like putting jumbled threads in order. When (one) has figured out the clue, (he can) sort out a thread as long as a billion yards (zhang) from a tangled mess. (If one) loses the clue, (he) is in difficulty even to tidy a thread (as short as) a (Chinese) foot or inch.]

Zhao's analysis: Since this Taizong Shilu record was written before the Manchu took over China proper, toktobuhangge in The Dictionary has the problem of time (or tense) dislocation. In addition, jang was the phonetic transliteration of Chinese zhang 丈, and c'y, of Chinese chi 尺. In 1748, the Qianlong emperor's Manchu standardization created the words juda to replace jang and sušuru to replace c'y.

Zhao's grammar guidance: facaha sirge means "the messy silk threads" (luansi 乱 丝). When the adjective gulhun is describing the verb hergimbi, which is derived into hergitu here, the Pentaglot Dictionary (Ch. Wuti Qingwen jian 五体清文鉴) translated gulhun hergitu into zhenghuang 整恍. Placing this phrase into the context of Shilu, it means "to wind the messy silk threads into order." In sum, this Shilu quotation uses the metaphor of winding the messy silk threads to recount the difficulty of the Manchu taking over China proper.

Uyuci debtelin [The ninth chapter], entry 40, The Dictionary, 355, and Zhao, 400.

Entry: uyun booi dolo bici, suwaliyame weile de dabu

Annotation: ere uyun booi dolo serengge, uthai uyun mukūn i dolo sere gisun inu. uyun boo seme gisurehengge, uyun mukūn seme gisurere ci fisen gargan hanci serebumbi. tuttu fe gisun de, uyun booi dolo bici. suwaliyame weile de dabu seme gisurembi: 
Zhao's Shunzhi Shilu quotation: sengge irgen aikabade uyun booi dolo bici, suwaliyame weile de dabu. tule bici, ume dabure. 者民, 凡在九家内者,一体连坐; 在外 者, 不得株连。 [(To) the man over sixty years old, if (he is) among the (members of the) nine families, count (him) in (to) be punished jointly [with the other members of the nine families]. If [he is] not [from the nine families], (then) don't link (him up) for the joint punishment. $]^{55}$

Zhao's analysis: Using uyun boo or "nine families" to mean uyun mukūn or "nine clans" indicates the two concepts, family and clan, were interchangeable among the early Manchu.

Juwanci debtelin [The tenth chapter], entry 31, The Dictionary, 387, and Zhao, 428-29.

Entry: tasha i fesingge menggun i doron

Annotation: ere fesingge sere gisun. uthai fesin ningge sere gisun inu. jafakūngga sere gisun de adali. tuttu fe gisun de tasha i fesingge menggun i doron seme gisurembi:

Zhao's analysis: The entry matches the Shilu record and the Chinese translation of this entry is huniu yinyin 虎鈕銀印. It means "a silver seal with a tiger(-shaped) handle." It is a mistake that The Dictionary annotation equates jafakūngga (an adjective which means you ba'er de 有把儿的, “something with a handle”) to fesingge (which is the combination of fesin and ningge and means ba'er de 把儿的, “handle's”).

Juwan emuci debtelin [The eleventh chapter], entry 14, The Dictionary, 418-19, and Zhao, 459-60.

Entry: ferguwecuke genggiyen fayangga banjibumbi

Annotation: ere ferguwecuke genggiyen fayangga banjibumbi serengge. uthai umesi sure sektu juse enen bahabumbi sere gisun. tuttu fe gisun de. ferguwecuke genggiyen fayangga banjibumbi seme gisurembi:

Zhao's Taizu Shilu quotation: abka gosici, juse omosi be yendebume, hūturi fengšen be badarambufi, ferguwecuke genggiyen fayangga banjibumbi. ferguwecuke genggiyen jui banjici, jai aide endebumbi? abka de waka sabuci, mentuhun warhūn juse be banjibumbi. mentuhun farhūn juse doro be siraci, efujerakūngge akū. 天果佑之'必昌 其子孙, 绵其福禄, 降以神智之嗣。宁有神智之嗣, 或致失德者乎? 若获罪于天, 则所生之子 必昏庸者流。以昏庸而继大业, 不致败亡者, 未之有也。 [(If) Heaven indeed blesses (him), (that blessing) will undoubtedly prosper (his) sons and grandsons, continue his luck

55. This writing is about a historical method of social control method in China. This method organized every ten families into a unit. Once a family had a criminal or criminals among the family members, the other nine families were obligated to report him/them to the authorities. If they failed to do so, the nine families would be punished together by the government. 
and wealth, (and) bestow upon (him) a successor with spiritual sanity. Is there an heir with spiritual sanity, (who) becomes a person of losing morality? If (a person) is guilty to Heaven, a son born from him must be among the fatuous. Undertaking the great cause by the fatuous, no decline and fall (of the polity) would be unheard of.]

Zhao's analysis: In this Shilu context, fayangga "the soul" is to mean the son. Thus, in this Shilu record, ferguwecuke genggiyen fayangga banjibumbi is directly translated into Chinese as (tian) shisheng shenming zhi hun (天)使生神明之魂 [(Heaven) lets (it) produce a soul of sanity] and is followed by ferguwecuke genggiyen jui banjici.

Juan juweci debtelin [The twelfth chapter], entry 5, The Dictionary, 430-31, and Zhao, 471-72.

Entry: meni jabtuhai teile. suweni ederi gisureme jimbi.

Annotation: ere jabduhai teile suweni ederi gisureme jimbi serengge, uthai šolo be tuwame suweni ubade gisureme jiki sere gisun. tuttu fe gisun de, meni jabduhai teile suweni ederi gisureme jimbi seme gisurembi:

Zhao's Taizong Shilu quotation: suwe aikabade gisurenjire be inenggi goidame obode, be meni jabduhai teile, suweni ederi gisureme jimbi. 若尔等来议之人, 日久 不至, 我即乘暇来此, 与尔等议之。 [If your people who come to discuss [the matter] do not arrive in many days, I will take my leisure time to come here (it meant to say "I will come as quickly as possible") and discuss [the matter] with you.]

Zhao's analysis and grammar guidance: jabtuhai teile means jingyidexiao 仅以得 暇 [just get leisure (time)] if translated into Chinese directly. To fit it into the actual meaning in Chinese, it is jinkuai 尽快, which means "(do something) as quickly as possible." Regarding ederi, it is the combination of pronoun ere and preposition deri, a result from fast oral speech (jidu zhi yin 急读之音 [the fast speaking tone]). In this case, the Shilu made a mistake to use ederi to write suweni ederi gisureme jimbi. It should use emgi (together) and make it suweni emgi gisureme jimbi.

Bibliography

Alonso de la Fuente, José Andrés. "On the Role of Grammaticalization (Recategorization) in the Origin of Manchu Motion Verbs." Cahiers de Linguistique Asie Orientale 45, no. 2 (2016): 11326.

An Shuangcheng 安双成. Man-Han dacidian 滿漢大辭典 [Manchu-Chinese Dictionary]. Revised edition. Shenyang: Liaoning renmin chubanshe, 2018.

Chia Ning. "The Manchu Language Resources in the People's Republic of China: A Comprehensive Review of Sixteen Manchu Textbooks." China Review International 16, no. 3 (2010): 308-22. 
Chuang Chi-fa 莊吉發. Manwen yuandang “Manwen yuandang” xuandu yizhu: Taizuchao (Yi) 滿文原 檔《滿文原檔》選讀譯註:太祖朝 (一) [The Original Manchu Archives, Selected and Annotated Original Manchu Archives: Taizu Reign, Part 1]. Taipei: Wenshizhe, 2020.

Chunhua 春花. Qingdai manmengwen cidian yanjiu 清代满蒙文词典研究 [Study of Manchu and Mongolian Dictionaries of the Qing Dynasty]. Shenyang: Liaoning renmin chubanshe, 2008.

Corff, Oliver et al., eds. Auf kaiserlichen Befehl erstelltes Wörterbuch des Manjurischen in fünf Sprachen „Fünfsprachenspiegel“. Wiesbaden: Harrassowitz Verlag, 2013.

Ferri, Rolando. "The Greco-Roman World." In The Cambridge World History of Lexicography, 84105, edited by John Considine. New York: Cambridge University Press, 2019.

Fu Li 富丽. Shijie manwen wenxian mulu 世界满文文献目录 [Global Catalog of Manchu Texts]. Beijing: Zhongguo minzu guwenzi yanjiuhui, 1983.

Gorelova, Liliya M. Manchu Grammar. Handbook of Oriental Studies. Section 8, Uralic \& Central Asian Studies, Volume 7. Leiden: Brill, 2002.

Huang Runhua 黄润华 and Qu Liusheng 屈六生. Quanguo Manwen tushu ziliao lianhe mulu 全国满文 图书资料联合目录 [National Union Catalog of Manchu Books and Materials]. Beijing: Shumu wenxian chubanshe, 1991.

He Ling 贺灵. “Qingdai Manwen wenxian gailun” 清代满文文献概论 [A General Introduction to the Manchu Literature of the Qing Dynasty]. In Xibo wenhua 錫伯文化 38 (2004). http://www. iqh.net.cn/info.asp? column_id $=8388$.

Imanishi Shunjū 今西春秋. Kōchū iikiroku 校注異域錄 [Tulišen's I-yü-lu]. Tenri: Tenri daigaku oyasoto kenkyūjo, 1964.

—. “Kyū Shingo yakkai” 旧清語訳解 [Chiu Ch’ing-Yü Translated and Explained], Monumenta Orientalia 3 (1969), 1-287.

Ji Yonghai 季永海. Manyu yufa 满语语法 [Manchu grammar]. Revised edition. Beijing: Zhongyang minzu daxue chubanshe, 2011.

Ji Yonghai 季永海, Liu Jingxian 刘宪景, and Qu Liusheng 屈六生. Manyu yufa 满语语法 [Manchu Grammar]. Beijing: Minzu chubanshe, 1986.

Jiu Qingyu cidian 旧清语辞典. Wulumuqi: Xinjiang renmin chubanshe, 1987.

Li, Gertraude Roth. Manchu: A Textbook for Reading documents. $2^{\text {nd }}$ edition. Honolulu, Hawaii: National Foreign Language Resource Center, 2010.

_. Manchu: A Textbook for Reading Documents. Honolulu, Hawaii: University of Hawai'i Press, 2000.

Liu Housheng 刘厚生. Manyu jiaocheng 满語文教程 [Course Materials for Manchu Language Teaching]. Changchun: Jilin wenshi chubanshe, 1992.

Liu Jingxian 刘景宪, Zhao Aping 赵阿平, and Zhao Jinchun 赵金纯. Manyu yanjiu tonglun 满语研 究通论 [General Theory of Manchu Language Studies]. Harbin: Heilongjiang Chaoxian minzu chubanshe, 1997.

Norman, Jerry. A Comprehensive Manchu-English Dictionary. Cambridge, Mass.: Harvard University Asia Center, 2013.

Söderblom Saarela, Mårten. "Public Inscriptions and Manchu Language Reform in the Early Qianlong Reign (1740s-1760s)." Saksaha: A Journal of Manchu Studies 16 (2019-20): 31-53.

Nobuo Kanda 神田信夫. “Cong Manwen laodang dao Manzhou jiudang” 从《满文老档》到《旧满洲挡》 [From the Old Manchu Archives to Fe Manju Dangse]. In Manxue yanjiu 满学研究, volume 3, 256-78, edited by Yan Chongnian. Beijing: Renmin chubanshe, 1996.

Tong Yonggong 佟永功. Manyuwen yu Manwen dang'an yanjiu 满语文与满文档案研究 [The Study of the Manchu Language and Manchu Archives]. Shenyang: Liaoning remin chubanshe, 2009.

Tong Yonggong 佟永功 and Guan Jialu关嘉禄. “Qianlongchao 'Qinding xin Qingyu' tanxi” 乾隆朝“ 
钦定新清语'探析 [Exploration and Analysis of the Imperially Commissioned New Manchu During the Qianlong Reign]. Manzu yanjiu 2 (1995): 66-70. https://www.ixueshu.com/document/ 7f17aaf10b644d71318947a18e7f9386.html. (accessed October 20, 2020).

von Möllendorff, P. G. A Manchu Grammar, With Analysed Texts. n.p.: HardPress Publishing, (1892) 2013.

Wu Yuanfeng 吳元丰. “Manwen laodang chuyi” 满文老挡刍议 [A Preliminary Discussion of the Old Manchu Archives]. Qingshi yanjiu 1, no. 1 (February 2011): 138-45.

Yan Chongnian 阎崇年. Ershi shiji shijie manxue zhuzuo tiyao 20 世纪世界满学著作提要 [Synopsis of the Global Works in Manchu Studies During the Twentieth Century]. Beijing: Minzu chubanshe, 2003.

——. “Wuquandian laodang ji Qianlong chaoben mingcheng quanshi”《无圈点老档》及乾隆抄本 名称诠释 [Old Archives Without Dot and Circle and the Interpretation of the Name for the Qianlong Manuscript]. Lishi yanjiu 3 (1998): 49-64.

Zhang Hong 张虹 and Cheng Dakun 程大鲲, trans., Tong Yonggong 佟永功, proofread. "Qianlongchao “Qinding xin Qingyu (1)” 乾隆朝“钦定新清语”(一) [Imperially Commissioned New Manchu of the Qianlong Reign (1)]. Manyu yanjiu 2 (1993): 79-84 and 55.

. "Qianlongchao 'qinding xin Qingyu (2)." Manyu yanjiu 2 (1994): 68-77 and 50.

. "Qianlongchao 'qinding xin Qingyu (3)." Manyu yanjiu 2 (1995): 51-58.

_. "Qianlongchao “qinding xin Qingyu (4).” Manyu yanjiu 2 (1996): 31-38.

. "Qianlongchao “qinding xin Qingyu (5)." Manyu yanjiu 2 (1997): 37-44.

Zhao Zhiqiang 赵志强. Jiuqingyu yanjiu一Manzhou zaoqi de yuyan yu wenhua《旧清语》研究——满 洲早期的语言与文化 [The Study of the Old Manchu Language-Language and Culture of the Early Manchu]. Beijing: Yanshan chubanshe, 2003. 